\title{
How 'Smart' Are Smart Specialization Strategies?
}

\author{
MARCO DI CATALDO, ${ }^{1,2}$ iD VASSILIS MONASTIRIOTIS ${ }^{2}$ iD and ANDRÉS RODRÍGUEZ-POSE ${ }^{3}$ iD \\ ${ }^{1} \mathrm{Ca}$ ' Foscari University of Venice, Venice, Italy ${ }^{2}$ European Institute, London School of Economics, London, United Kingdom ${ }^{3}$ Cañada \\ Blanch Centre and Department of Geography and Environment, London School of Economics, London, United Kingdom
}

\begin{abstract}
The introduction of smart specialization (S3) as a fundamental pillar of the 2014 reform of the EU cohesion policy is a significant strategic shift in European development intervention. S3 strategies aimed at mobilizing the economic potential of each country and region of the EU by allowing a more place-based and bottom-up approach to development. However, despite the salience that S3 has acquired in a short period of time, there has been no European-wide evaluation of the extent to which S3 strategies truly reflect the economic characteristics and potential of the territories where they are being implemented. This article examines the characteristics of S3 strategies across Europe - by focusing on their development axes, economic or scientific domains and policy priorities - to assess whether this is the case. The results show that S3 strategies display a proliferation of objectives, a problem that particularly affects areas with weaker quality of government. Moreover, strategies are generally loosely connected with the intrinsic conditions of each region and mostly mimic what neighbouring areas are doing. The lack of more concise and focused S3 strategies is likely to undermine the effectiveness of what is, otherwise, a very interesting and worthwhile policy experiment.
\end{abstract}

Keywords: smart specialization; EU policy; regions; Europe

\section{Introduction}

Smart specialization (S3) occupies a special position in European policymaking. Analytically, the concept has its intellectual origins in the literature on innovation policy and on new forms of industrial policy. However, the concept is still far from being fully articulated. This has not prevented it from gaining powerful traction in the realm of policy, becoming, since the 2014 reform, one of the backbones of the EU regional development policy, which itself is a fundamental constituent of the EU's cohesion policy. As noted by Foray et al. (2011):

Elaborated by a group of academic 'experts' in 2008, [smart specialisation] very quickly made a significant impact on the policy audience, particularly in Europe. [...] Such a success story in such a short period of time is a perfect example of 'policy running ahead of theory': while smart specialisation seems to be already a policy hit and policy makers show some frenetic engagements towards smart specialisation, the concept is not tight in particular as an academic concept. (Foray et al., 2011, p. 3)

But what is smart specialization? And why is it so important in the EU's cohesion policy? Following Midtkandal and Sörvik (2012, p. 1), smart specialization is a process aiming to develop a vision in order to identify the areas of intervention of greatest strategic potential in every territory. As such, it represents a place-based development strategy that includes not only identifying, through what is known as the 
entrepreneurial discovery process, where the potential of every territory lies, but also developing a system of governance involving multi-stakeholder mechanisms in order to set strategic priorities and systems of intervention (Midtkandal and Sörvik, 2012, p. 1).

The adoption of smart specialization has been one of the key elements of European policy since 2014 and is a significant strategic shift in cohesion policy. The aim of the reform was not only to improve the effectiveness of the policy at large (for example, by improving the sectoral targeting of funding and creating production synergies), but also to introduce a new way of thinking about local economic development: from a 'one-size-fits-all' to a more place-based intervention, from a top-down approach to a more bottom-up one and from an objective of economic convergence among European regions to a multitude of objectives adapted to the conditions and potential of every region.

Smart specialization has been designed as a policy mechanism that can support regions (and countries) to unleash their growth potential by helping them identify and harness their dynamic (and latent) comparative and competitive advantages.

As a new policy and new concept, however, there is still limited knowledge about its effectiveness and impact. Because it was implemented for the first time on a large scale during the programming period 2014-20 - and despite some early attempts at assessing its impact (Crescenzi et al., 2020; Gianelle et al., 2020; Iacobucci and Guzzini, 2016; McCann and Ortega-Argilés, 2016) - it will take some time after the end of 2020 for a concrete picture of its effectiveness to emerge. What is surprising, however, is that there are very few accounts of how S3 strategies across Europe really reflect the endogenous potential of all regions for which an entrepreneurial discovery process was conducted and, subsequently, a smart specialization strategy drafted. In other words, we lack a complete picture of how 'smart' smart specialization truly is.

This is what this article intends to do. We set out to offer a comprehensive analysis of the population of regional S3 strategies currently in operation in the EU with the aim of assessing how independent they are from one another and how they are influenced by differences in economic and institutional characteristics - quality of government, economic and technological capacities - across regions of Europe.

To do that, we first document and analyse some key features of the population of S3 strategies, focusing on the prevalence of different economic and scientific domains and policy objectives within and across regions (the breadth of specializations per region and the coincidence of specializations across regions). We then examine how groups of regions cluster with regard to their economic priorities (domains) and through this we identify five distinct clusters of (smart) sectoral specializations across the EU. Last, we perform an exploratory analysis of key features of the $\mathrm{S} 3$ strategies across space, seeking to understand whether the policy approach as a whole contributes to a smarter policy at an aggregate level - in other words, whether the smart strategies adopted at the local level truly match the local economic context and can therefore be taken as a suitable approach for mobilizing the economic potential of Europe as a whole. This is achieved by assessing, using regression analysis, the drivers of the observed heterogeneity in the key characteristics of regional strategies, offering a unique insight into how the policy creates or resolves spatial divisions in Europe. 


\section{Smart Specialisation: Concept and Practice}

\section{What Is Smart Specialization?}

The concept of smart specialization is based on the idea that each territory should concentrate their development intervention in certain areas of specialization where there is a significant potential or competitive advantage to sustain productivity growth (Foray et al., 2009; Asheim et al., 2017). This idea emerged following widespread criticism of the one-size-fits-all policy approaches and the vision that development interventions should be built around existing place-based capabilities and potential (Barca, 2009; Barca et al., 2012; Foray et al., 2009, 2011; McCann and Ortega-Argilés, 2015). Smart specialization was conceived as an answer to questions about how to define targets for place-based policies (Balland et al., 2019). The answer proposed by the 'Knowledge for Growth' expert group (Foray et al., 2009) was that territories should develop their competitive advantage around sectors where they possess existing strengths, thus leveraging those capabilities.

According to this approach, context matters for the evolution of innovation and economic systems. Territories' development pathways are fundamentally driven by ongoing dynamics and inherited socioeconomic or institutional structures. Hence, each place should design its development strategy with the aim of fostering specialization in knowledge-related sectors, depending on already existing assets (McCann and OrtegaArgilés, 2015) and according to the principles of 'diversified specialisation' (Farhauer and Kröll, 2012). Consequently, policy prioritization in each S3 strategy should be ordered by looking for development opportunities in selected domains where a particular territory has advantages or a greater potential (David et al., 2009; Foray et al., 2009, 2011).

While the formulation of smart specialization was initially that of a purely sectoral policy with no spatial dimension, its proponents later came to the conclusion that this approach had great potential for the promotion of economic growth at the regional level, in particular (McCann and Ortega-Argilés, 2014; Foray, 2015). This conceptualization of S3 recognizes the uniqueness of local areas and their economic trajectories and assumes that each region should develop its own, unique place-specific development plan. This applies as much to economically strong regions as to weaker ones. For lagging territories, smart specialization is seen as a way to concentrate resources in a few sectors with sufficient potential to achieve long-lasting economic impacts (Foray et al., 2009; Foray, 2015).

The entrepreneurial discovery process inherent to every S3 strategy implies identifying the economic and technological sectors in which to invest, based on a number of guidelines. First, interventions should support regional embeddedness by identifying activities that have the greatest possibility of generating significant economic impacts (Fedeli et al., 2019). Second, they should enhance linkages across domains, prioritizing sectors that would eventually lead to 'related diversification'; namely, the development of technological activities related to existing knowledge bases (Balland et al., 2019), following fundamental aspects of evolutionary economic geography, such as path dependency and related variety (Asheim et al., 2011; Boschma and Iammarino, 2009; Frenken et al., 2007). Third, S3 requires experimentation and innovation in policy design, together with timely monitoring and evaluation and the constant involvement of local actors (Fedeli et al., 2019; Foray et al., 2011; Foray, 2015; McCann and Ortega-Argilés, 2015). 
Thus, S3 strategies assign a central role to regional government authorities. They are expected to perform a rigorous self-assessment of local potential, involving the key economic agents who are active in the territory (Boschma, 2014).

The conceptual underpinnings of smart specialization informed both the reform of the EU's cohesion policy for the 2014-20 programming period and the Europe 2020 agenda, implying that EU development policies require regions to adopt place-based policies tailored on their existing economic assets through the collaborative involvement of local communities and institutions. Smart specialization has become an ex ante conditionality of cohesion policy (Charles et al., 2012), as every EU region had to submit their S3 strategies in order to be eligible for EU funding (Iacobucci, 2014). To help regions develop their S3 strategies, the European Commission established a platform hosted by the EU Joint Research Centre in Seville, offering regions guidance and support in identifying their most promising areas in terms of economic opportunities (Fedeli et al., 2019).

\section{Potential Shortcomings of $S 3$}

One of the recurrent critiques of S3 is that it may promote a culture of picking winners, protecting already existing industrial champions (Fedeli et al., 2019). However, the smart specialization concept prescribes a strategy of 'choosing races' (Hughes, 2012), which implies betting on potentially successful domains. This is what makes S3 truly place-based and applicable to both more and less developed regions. The policy assumes that there is room for profitable investments also in areas where the ground for economic growth may initially seem less fertile. Yet a number of pre-existing conditions that may be found in peripheral regions, such as limited entrepreneurial spirit, the lack of industrial diversity or inadequate market size, entail that identifying policy priorities in backward areas is complicated (Iacobucci and Guzzini, 2016). This perceived lack of potential may lead backward regions to choose rather large areas of specialization, selecting a high number of investment domains at the expense of existing sectors (Boschma, 2014; Capello and Kroll, 2016).

A similar issue may arise if resources are misallocated towards existing industrial targets for purely political interests and rent-seeking (Camagni et al., 2014). This would happen if policy priorities are not established on the basis of economic logic and are, therefore, disconnected from the needs of local communities. This is far more frequent if local governments are corrupt or lack the basic competences to produce effective policies. Hence, poor institutions and the low quality of the local government represent substantial barriers for the successful design and implementation of S3 strategies (Capello and Kroll, 2016; Incaltarau et al., 2020; McCann and Ortega-Argilés, 2015; RodríguezPose, 2020; Rodríguez-Pose and Di Cataldo, 2015; Rodríguez-Pose et al., 2014). The bottom-up nature of S3 implies that local actors - especially policy-makers - hold large responsibilities in the design and implementation phases, meaning that poor local government quality may jeopardize the capacity to select areas of intervention in a truly effective manner (Farole et al., 2011).

Another issue complicating the operationalization of S3 strategies is that it has become an ex ante conditionality for 2014-20 cohesion policy. This fast conversion from theory to practice implies that policy intervention has taken place without a solid evidence base and without adequate scrutiny of its strengths and weaknesses (Morgan, 2015). There has 
been a limited exchange of experiences across jurisdictions that would indicate how to properly apply S3 in each context (Morgan, 2015). This fast adoption has been criticized - even by the creators of the S3 concept themselves (Foray et al., 2011).

\section{Early Evaluations}

Given its novelty, there has been little research of the effectiveness in the application of S3 strategies, but some analyses are starting to emerge. Iacobucci and Guzzini (2016), for example, consider the way in which S3 sectoral priorities have been defined by Italian regions, revealing that key concepts such as the 'relatedness' and 'connectivity' of technological domains have been overlooked as guiding principles behind S3. Mostly, interventions have been defined using intuition and anecdotal evidence and, in a majority of cases, without any clear justification. Furthermore, identifying areas of specialization has been more complicated in weaker regions (Iacobucci and Guzzini, 2016). Poor institutions were at the root of these flaws, leading to what has been deemed as too broad, not sufficiently embedded, or irrelevant S3 priorities in backward areas of Italy.

Gianelle et al. (2020) have examined the way that S3 priorities have been defined in Italian and Polish regions. They note that, while in some cases the chosen investment activities represent suitable $\mathrm{S} 3$ priorities, in at least 11 of 39 regions the innovation areas prioritized in S3 strategies do not reflect the expected S3 criteria. They reveal that S3 in some regions, far from providing clear targets, identify far too large a number of priorities, covering basically all economic areas, thus contradicting the basic S3 principle of selective intervention.

Finally, while a full impact analysis of S3 cannot be conducted yet, because of the newness of the strategies, Crescenzi et al. (2020) provide evidence on the effectiveness of a precursor of S3 interventions: the requirement for local businesses in the south of Italy to submit project applications based on the identification of their own priorities and collaboration strategies with other firms and other research-active local stakeholders to secure R\&D funding during the programming period 2007-13. The authors report that the project had a limited impact on additional investment, value added and employment, because of 'overshooting' - selecting technological domains that were too advanced with the aim of maximizing the chances of receiving funding, but that failed to create synergies with the local production structure (Crescenzi et al., 2020).

However, to our knowledge no research so far has analysed how focused S3 strategies are and how this may relate to the local economic context of each region. From the related literature we know that the design, deployment and overall effectiveness of regional development policies are influenced by the characteristics - institutional, economic or other - of the regions. For example, Crescenzi (2005) has shown that for EU regions the effectiveness of local innovation policy is conditioned by local characteristics, such as their geographical accessibility and their levels of human capital. In the case of the common agricultural policy, Henke et al. (2018) indicate that the effectiveness of policy implementation is influenced by national norms and institutional path dependencies. A more extensive literature exists on what determines the success and failure of cohesion policy (Crescenzi et al., 2017; Crescenzi et al., 2020) identifying a range of factors including the type of expenditures prioritized (Rodríguez-Pose and Fratesi, 2004), the coordination of expenditures with other policies (Crescenzi et al., 2015) and, more recently, the 
targeting of expenditures to meet regional needs (Di Cataldo and Monastiriotis, 2020) or to build on existing regional strengths (Sotiriou and Tsiapa, 2015). Informed by this literature, our analysis of the features of smart specialization strategies constitutes a unique attempt to assess aspects of policy design in this new policy area.

\section{Descriptive Features of Smart Specialization Strategies}

The analysis uses the information on the $\mathrm{S} 3$ strategies adopted by European regions, as recorded by the European Commission's Joint Research Centre (JRC) in its Smart Specialisation platform. ${ }^{1}$ This database collects all the S3 strategies from every territory (country or nomenclature of territorial units for statistics [NUTS1/NUTS2/NUTS3] region), including the date (from 2014 onwards) in which the strategy was submitted to the platform. For each territory, the platform reports the full set of sub-strategies ${ }^{2}$ adopted under the S3 framework. For each of these it lists the sectors of economic activity (labelled economic domains according to Eurostat's nomenclature of Economic Activities 2 sectoral classification) on which investment efforts will focus, as well as the scientific domains associated with them, defined using the NABS2007 nomenclature for the analysis and comparison of scientific programmes and budgets. Finally, the platform lists, for each axis, its policy objectives; namely, the broad areas of intervention to which it will contribute. These are related to the societal grand challenges identified in Horizon 2020 and the headline policies in the innovation union flagship initiative. They include nature and biodiversity, sustainable innovation, creative and cultural industries, key enabling technologies, social innovation and the digital agenda.

The coding of the strategies along the key dimensions (economic and scientific domains and policy objectives) is conducted by policy experts at the Joint Research Centre of the European Commission in Seville. Although any coding involves potential problems of misclassification, the fact that the task is undertaken by one team ensures consistency in the classifications produced. In our analysis our examination of the S3 strategies assumes that the official information about them is not systematically inaccurate in any of the dimensions that we discuss here.

\section{Mapping S3 Strategies}

Our starting point is a visual representation of $\mathrm{S} 3$ strategies across Europe for all countries and regions that submitted S3 strategies to the European Commission for the 2014-20 period. Figure 1 depicts the number of axes in each S3 strategy, providing a descriptive picture of regions and countries with ongoing S3 strategies, with Figure 1a showing national-level strategies and $1 \mathrm{~b}$ showing sub-national ones. As can be seen, although S3 was conceived as part of EU regional policy, it has also been adopted by a substantial number of countries at the national level; while in a number of EU countries - Portugal, Germany, Greece, Austria, Denmark, Poland, Romania and Sweden - both regional and nationwide S3 strategies have been adopted. In the remaining EU member states, S3 is conducted either at the national (such as in Latvia or Slovakia) or regional (such as in Belgium, France, Italy) level. Some non-EU countries have also been lured by the glow

\footnotetext{
${ }^{1}$ Retrieved from https://s3platform.jrc.ec.europa.eu/map.

${ }^{2}$ Henceforth, we refer to these as axes, to avoid conflation with the overall S3 strategies of regions/territories.
} 
Figure 1: Number of axes within each S3 strategy (countries and regions). (a) National axes, (b) regional axes. Note: (a) reports the number of axes in European countrywide S3 strategies; (b) reports the number of axes in regional S3 strategies. EU borders at the beginning of the 2014-20 period in bold outline.

(a) National axes

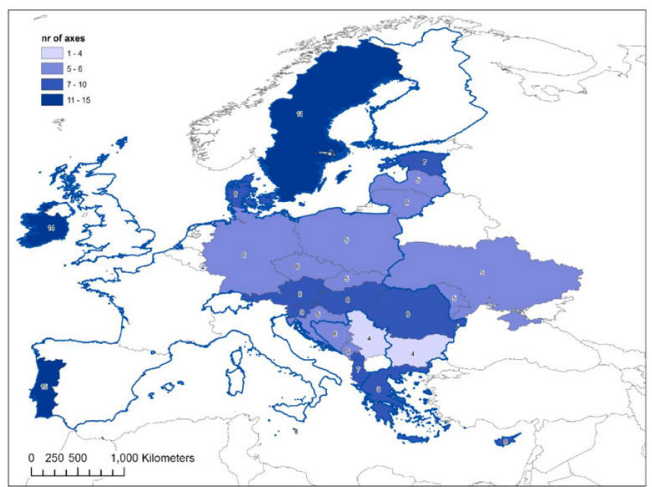

(b) Regional axes

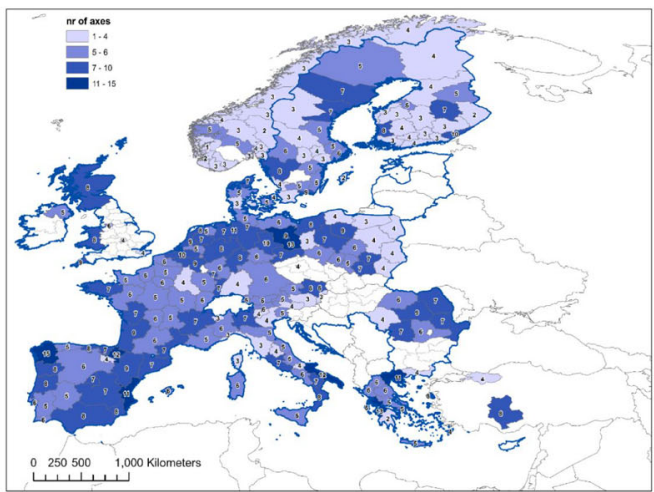

Note: panel (a) reports the number of axes in European countrywide S3 strategies; panel (b) reports the number of axes in regional S3 strategies; EU borders at the beginning of the 2014-2020 period in blue bold.

of S3, either at national (Ukraine, Bosnia-Herzegovina, Serbia, Montenegro, Moldova and Albania) or regional (Norway and two Turkish regions) level. ${ }^{3}$ Finally, Figure $1 \mathrm{~b}$ shows the NUTS level at which regional S3 strategies have been designed and implemented varies across European countries. In Germany, smart specialization strategies are being conducted at NUTS1 (the Länder) level. In most other countries the level chosen is NUTS2. In Scandinavian countries the level is NUTS3. A peculiar case is that of the UK, where all NUTS1 home countries - England (not shown in the map), Wales, Scotland and Northern Ireland - have submitted a strategy, while a small number of NUTS2 regions in England also have one.

Figure 1 also shows that the number of axes within each S3 strategy differ widely across Europe. The country with the largest number of axes is Portugal, with 15, while Bulgaria has only four (Figure 1a). At the regional level the difference is even sharper. Galicia in Spain has 15, while Peloponnese in Greece is limited to two and Hordaland in Norway to only one (Figure $1 b$ ).

Figure 2 presents the number of economic and scientific domains identified by each S3 regional strategy, while Figure 3 displays the number of policy objectives. Economic and scientific domains are the key investment targets of S3 strategies and are intended to indicate the sectors in which the region aims to specialize. It is evident from Figure 2 that some S3 strategies have disproportionally high numbers of economic and scientific domains. Hence, the main conclusion is that in many EU regions there has been a proliferation of both economic and scientific domains for S3 strategies (Figure 2). Such proliferation is prevalent in Spanish regions. Over 30 economic domains are listed in Navarra, Aragón, Castilla-La Mancha, Murcia and Andalucía. Valencia, Cataluña,

\footnotetext{
${ }^{3}$ EU's neighbouring countries and candidate member states were given the opportunity to participate in the S3 programme (https://s3platform.jrc.ec.europa.eu/eu-neighbourhood).
} 
Figure 2: Number of (a) economic and (b) scientific domains of S3 strategies by region.

(a) Economic domains

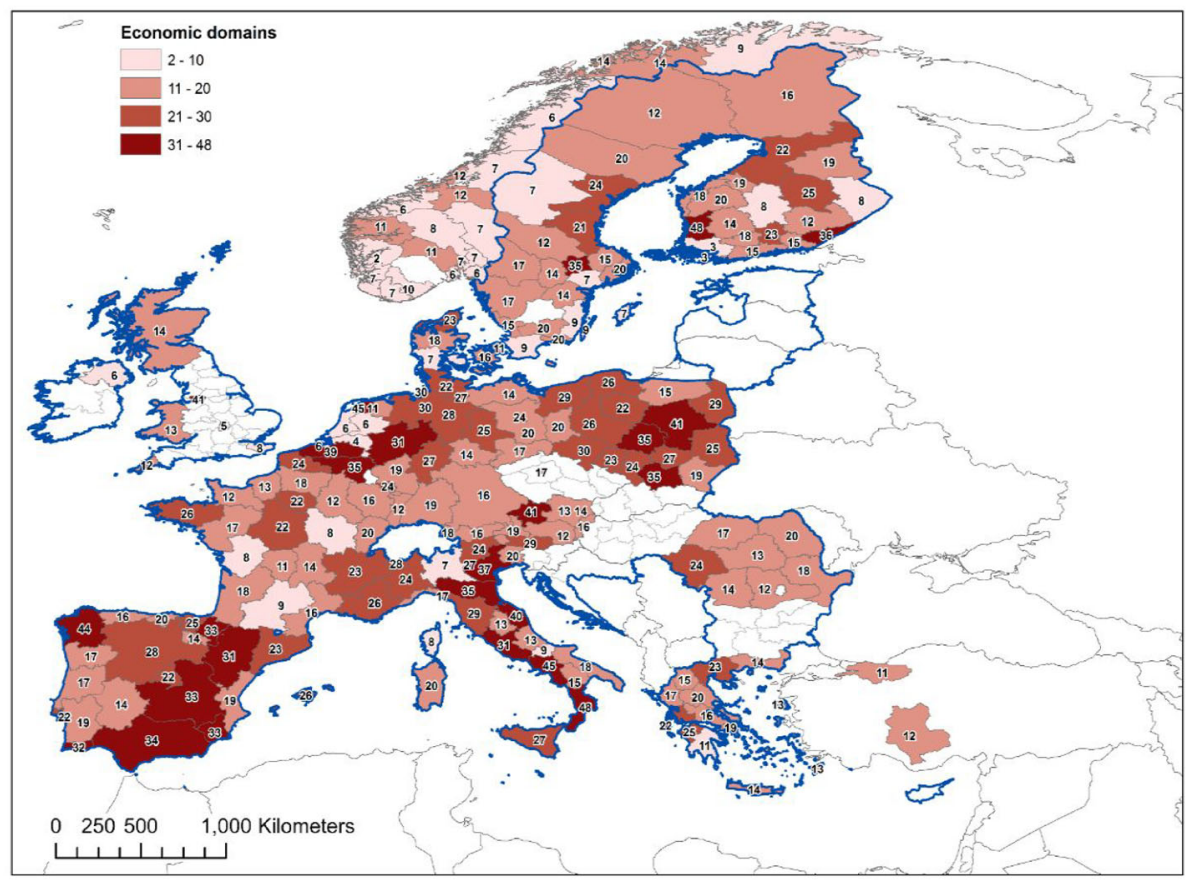

(b) Scientific domains

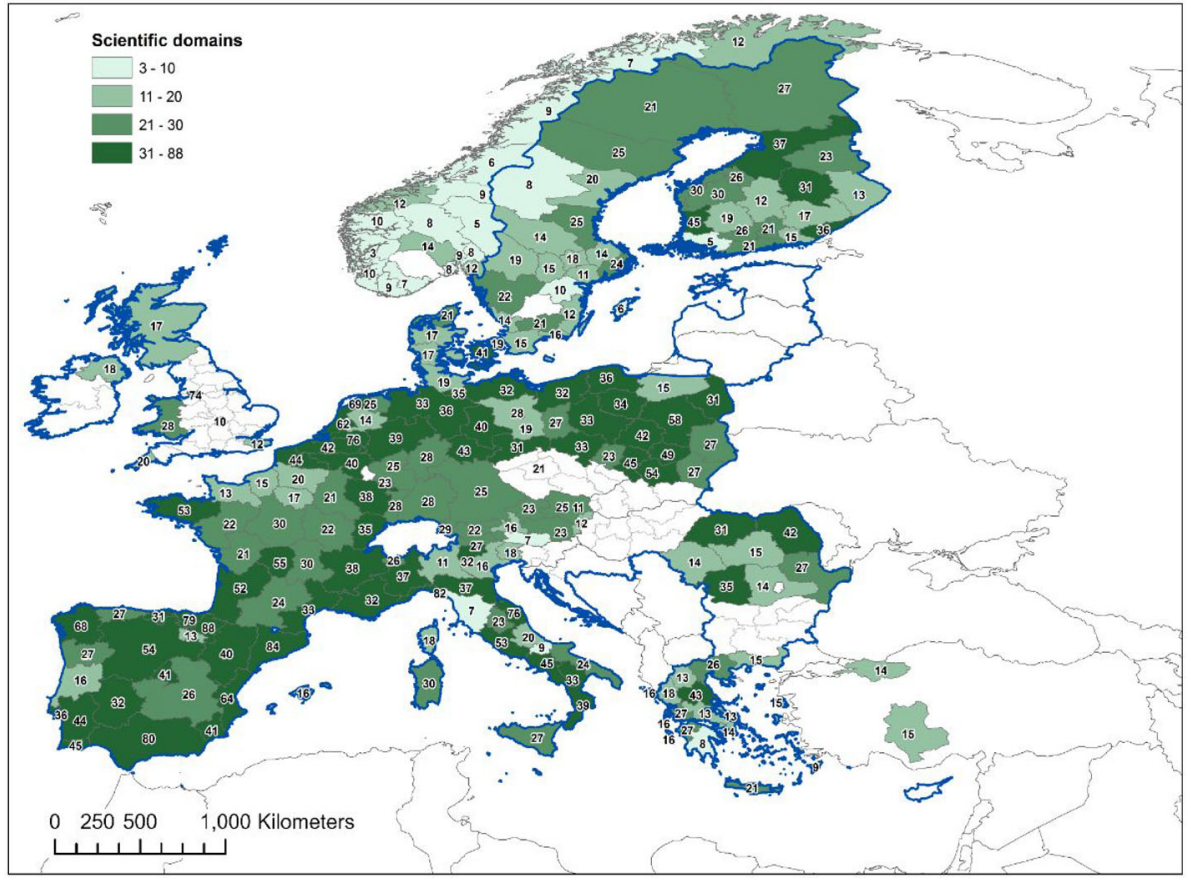


Figure 3: Number of policy objectives of S3 strategies by region.

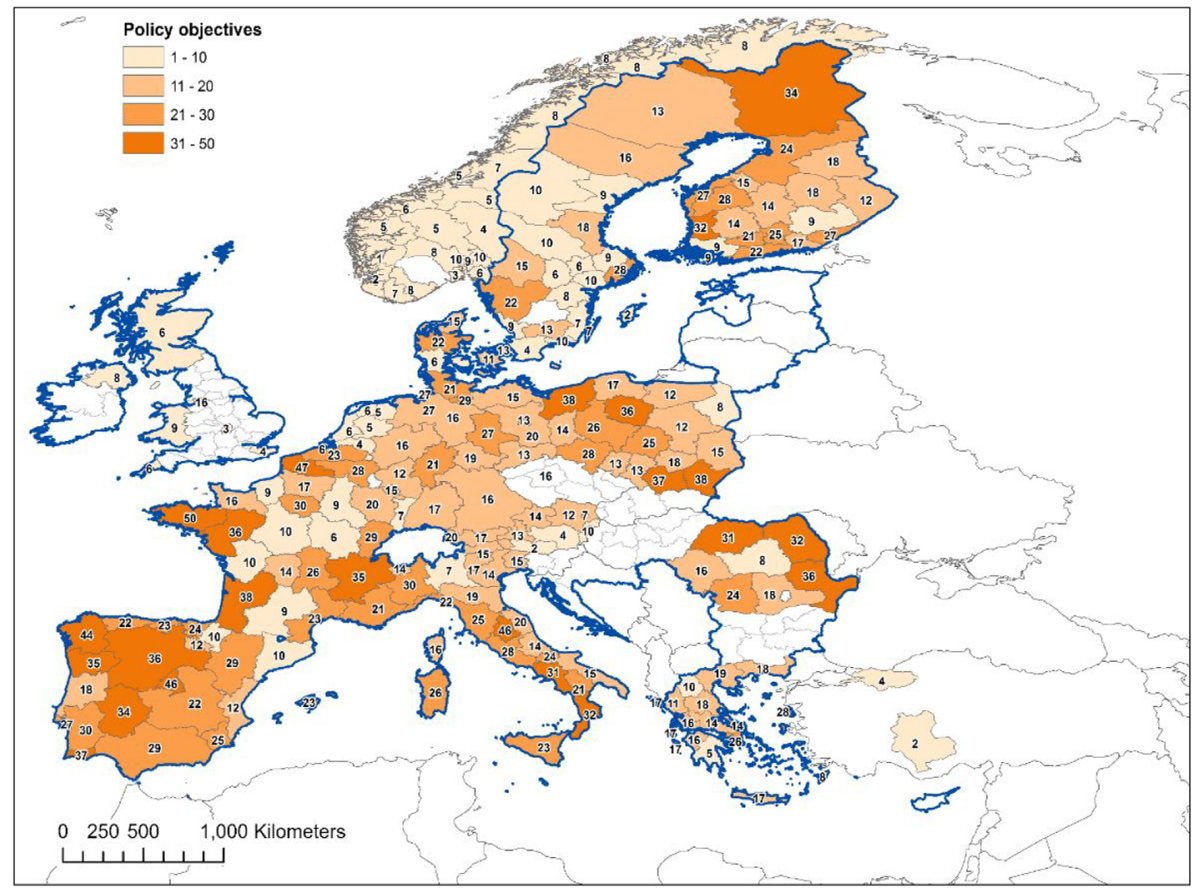

Andalucía, Galicia, the Basque County and Navarra identify more than 60 scientific domains among their priorities. Navarra tops the S3 ranking with 88 scientific targets.

Many Belgian, Dutch, French, Italian and Polish regions are similarly ambitious in terms of economic and scientific domains. The region of Calabria lists 48 economic domains, Groningen and Campania 45, Mazovia 41, Marche 40 and Flanders 39. The Italian regions of Calabria, Campania, Marche, Emilia-Romagna and Lazio all have over 30 scientific domains in their S3 strategy (76 in Marche alone). Of the 16 voivodships in Poland, all but five have strategies with over 30 scientific domains. Internal contrasts in the number of scientific domains within countries are conspicuous. Whereas Tuscany lists only seven scientific domains and Lombardy - the largest region in Italy - 11, Marche has a total of 76. In France, Limousin boasts 55, while Île-de-France included only 17. And in Greece, the starkest contrast is between 43 in Thessaly, on the one hand, 14 in Attica and eight in the Peloponnese, on the other.

The number of policy objectives also varies sharply, ranging from the single-digit figure of almost all Norwegian regions to very high figures in many Spanish, Romanian, Italian, Polish and French regions. Bretagne, in France, is the region with the highest number of policy targets in its S3 strategy, with 50 identified objectives.

It should be noted that the presence of a large number of areas of specialization does not necessarily reflect a lack of smartness in any particular strategy. Indeed, S3 strategies are not about selecting sectors per se - but rather about identifying missions (Mazzucato, 2018); namely, sets of activities across sectors that contribute to a particular specialization (see also Rodrik, 2004). It should therefore not be a surprise if some 
regions' S3 strategies list an unusually large number of domains. However, given that most regional S3 strategies list 18 economic domains or fewer, our sense is that strategies that list economic domains well above this number - which are perhaps half or more of the entire set of sectors in the economy - are perhaps not sufficiently fine-tuned. To a sceptic, given that the sectors listed in S3 strategies are de facto potential beneficiaries of cohesion policy funds, the implied proliferation of specializations in some S3 strategies may even be a signal that some strategies are driven by a 'something for everybody' logic. In this regard - and to the extent that it may be true - there is scope for improvement in the logic, focus and precision of the regional specializations pursued in the S3 framework.

\section{Are S3 Strategies Truly Distinctive?}

Besides the point raised above, the widespread proliferation of economic and scientific domains and policy objectives questions additionally, and to a considerable extent, how smart S3 strategies truly are. Many European regions seem incapable of truly identifying a narrow list of priorities - and the EU similarly incapable of curtailing the multiplication of policy objectives. The proliferation of domains may also signal an inability to present distinctive regional strategies that would reflect the conditions and potential of each individual region. To assess whether S3 strategies across Europe are sufficiently distinctive or if, inversely, they overlap significantly in their priorities and thus reproduce the same economic and innovation domains and the same policy priorities over and over again, we proceed as follows. First, we examine the frequency of different domains across regional strategies - looking at the sectoral, scientific and policy content of each strategy. Second, we perform a cluster analysis, this time only for the economic domains, aiming at classifying regions into groups of specializations. ${ }^{4}$

Table 1 lists the 20 most frequent economic and scientific domains and policy objectives in the 244 S3 national and regional S3 strategies analysed. A number of domains occur across a high share of S3 strategies, indicating either that many territories have overlapping specializations or that there is a tendency to repeat strategies among countries and regions. Altogether 169 territories (or 69\% of the total) identify 'information service activities' as one of their specializations. 'Computer programming' appears as a priority in $68 \%$ of strategies. 'Health promotion' is the most common scientific domain, covered by $67 \%$ of strategies and an implausible 157 (64\%) specialize in medical sciences. A similar example for the policy objectives is the case of advanced materials, which forms part of the specialization strategies of 131 regions and countries in the EU.

These frequencies indicate that very similar priorities are present across many S3 strategies, raising the important question of the extent to which the S3 framework is producing strategies that both adequately identify the characteristics of each territory and, at the same time, are collectively rational or appropriate, at the EU-wide level.

The evidence from our cluster analysis ${ }^{5}$ is partly reassuring in this regard. S3 strategies in Europe cluster into five distinctive groups, each with a reasonable geographical spread

\footnotetext{
${ }^{4}$ Our analysis was conducted at the regional level but included the S3 strategies of countries where no sub-national S3 strategies exist.

${ }^{5}$ We performed a partition (non-hierarchical) clustering using the cluster k-means command in Stata. The number of clusters was decided based on the Calinski-Harabasz pseudo-F.
} 


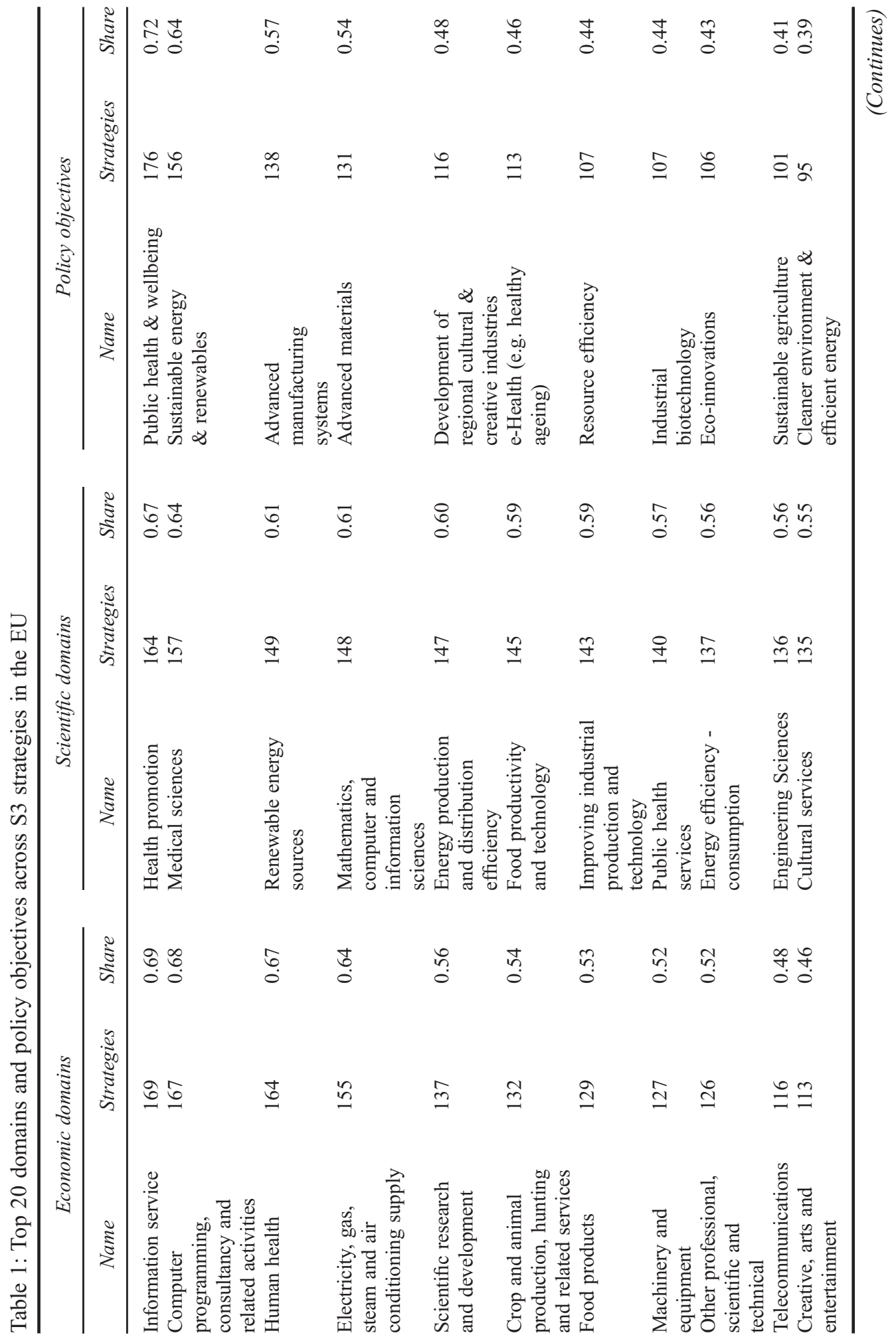




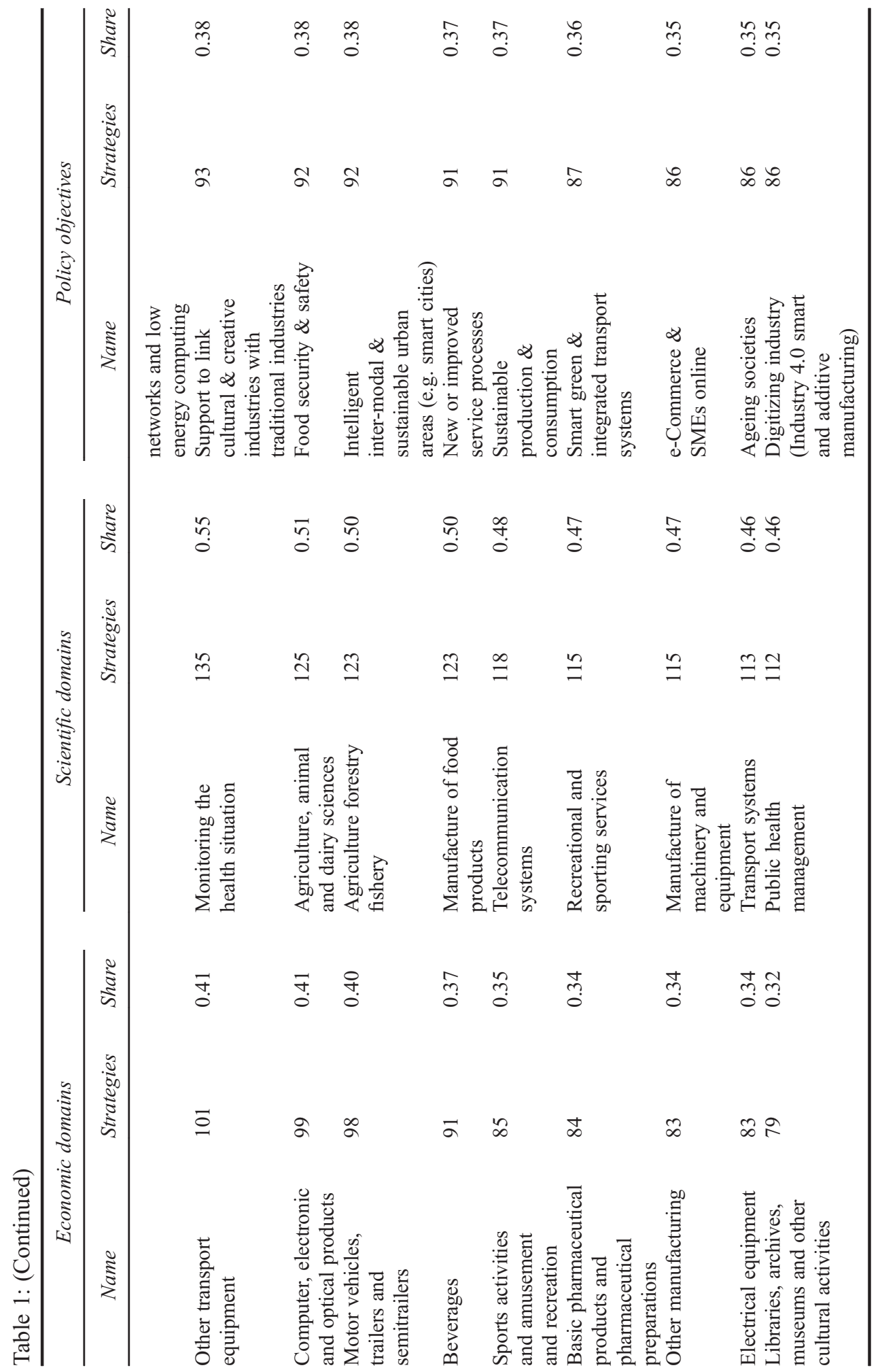


(Table A1 in the Appendix). Based on their prevalent specializations, ${ }^{6}$ the groups can be labelled as follows: (1) food and metal manufacture; (2) agri-food and hospitality; (3) ICT and health; (4) creative and leisure; (5) energy and resources. This clustering covers a reasonably wide range of economic domains with meaningful sectoral linkages (for example, agri-food is connected with hospitality). Moreover, the membership of territories in these clusters also appears to relate reasonably well to the existing specializations of the territories (for example, the creative and leisure cluster - cluster 4 in Table A1 - includes mainly tourist areas; while the agri-food and hospitality cluster - cluster 3 in Table 1 includes most of the regions with existing specializations in agriculture, food processing and food services) - while the clusters themselves are not spatially fragmented (reproducing, for example, a north-south division).

Thus, on the whole, our statistical review of the S3 strategies reveals two patterns: on the one hand, regions do appear to specialize in economic domains that are relevant, in the sense that they relate to the existing strengths and specializations of the regions; on the other hand, across the EU space we observe a relative proliferation of specializations (too many regions specializing in too many economic domains), which produces significant overlaps in specializations across territories. This leads to an important preliminary conclusion for our analysis: S3 strategies may be individually smart, but collectively sub-optimal. Our analysis in the next section moves beyond this observation, focusing on examining the local economic and institutional factors that possibly account for the observed variation in the degree of specialization of S3 strategies across territories.

\section{Drivers of Regional S3 Strategies}

In this section we perform an econometric analysis that examines how particular regional characteristics relate to some of the features of S3 strategies discussed above; namely, the numbers of axes, economic and scientific domains and policy objectives appearing in the S3 strategy of each territory.

Our goal is to verify whether these aspects are linked to the structural conditions of EU regions. In the absence of prior theoretical knowledge about the drivers of key aspects of S3 strategies, the analysis includes a broad range of explanatory variables covering various economic, labour market, geographical, socio-demographic and institutional regional characteristics. ${ }^{7}$ The rationale for including these variables, and our expectations with regard to the types of effects that they may relate to, are as follows.

To examine whether the economic capacity of regions exerts an influence on the characteristics of S3 strategies, we include alternatively two measures of agglomeration: population density and log-population. As is widely discussed in the new economic geography and urban economics literature (Combes et al., 2008), agglomeration is a key factor linked to productivity and consumption externalities and, by implication, to greater degrees of diversification. Thus, we expect that higher degrees of agglomeration will also create potential for regions to plan their 'diversified specialisations' strategically

\footnotetext{
${ }^{6} \mathrm{We}$ define domains as prevalent if they appear in the strategies of at least $70 \%$ of territories in any particular group.

${ }^{7}$ All variables are measured as averages for the 4 years prior to the beginning of the 2014-20 period (mean values for 201114). This ensures that variables are measured in the period prior to the implementation of $S 3$ strategies and hence cannot be affected by it, thus minimizing any endogeneity concerns.
} 
(Farhauer and Kröll, 2012). We also include two measures of economic performance, reflecting each region's position in the economic cycle: GDP per capita growth and unemployment. The former captures the economic dynamism of each territory: with higher rates of growth, a region can presumably afford to be more strategic in its S3 strategies for the future, thus deciding to specialize in fewer domains; or instead it could feel empowered to experiment more, thus potentially opting for more - or at least more risky - specializations. The latter captures instead the extent of slack in the economy and thus possibly more immediate pressures on policy, including for electoral reasons (Mechtel and Potrafke, 2013), leading regional policy-makers to 'spread their bets', thus producing more 'profligate' strategies. Our model also includes proxies for the technological capabilities and available set of skills of places, measured by the log of patent applications per million inhabitants ${ }^{8}$ and the share of adult population with higher education, respectively. As S3 strategies are expected to leverage on existing knowledge and innovation strengths, we expect that regions with higher technological capabilities will be able to support a broader number of economic and scientific domains in their strategies. ${ }^{9}$ Last, we expect that the quality and characteristics of S3 strategies will depend heavily on the administrative capacities of the regions and on their overall quality of government (QoG) (Rodríguez-Pose and Di Cataldo, 2015). We thus introduce a measure of regional government quality in our analysis, adopting the widely employed QoG EU regional indicators developed by the University of Gothenburg (Charron et al., 2014).

Formally, we estimate the following model with ordinary least squares (OLS):

$$
S 3_{r}=\alpha+\beta X_{r}+\varepsilon_{r}
$$

where $S 3_{r}$ is one of the four characteristics (number of axes, economic domains, scientific domains and policy objectives) of S3 strategy in region $r^{10} ; X_{r}$ represents the vector of regional-level explanatory variables; $\varepsilon_{r}$ is the error term.

As the definition of S3 goals and priorities in every single strategy may not follow exclusively the identification of local potential, other elements may shape S3 strategic choices at a regional level. One important factor potentially shaping the strategy is what neighbouring regions are doing. When designing their own S3 strategies regional decision-makers and officials may be concerned with or guided by neighbours' strategies for a number of reasons. First, they may consider that replicating or mimicking what is done elsewhere is the best way to secure funds (Revelli, 2002). Second, they may not want to be outdone by their competitors in numbers of goals and priorities due to considerations of territorial or yardstick competition (Gordon, 2010; Rodríguez-Pose and

\footnotetext{
${ }^{8}$ Patents are an imperfect proxy for innovation, but, for lack of a better alternative at the regional level, they have been frequently used in the literature looking at regional-level EU innovation capacity (Bottazzi and Peri, 2003). A potential alternative would be to use data from the EU regional innovation scoreboard. However, as this is available for few of the regions with ongoing S3 strategies, using this variable - which correlates $90 \%$ with log patents for the available data - would have implied losing many observations in the analysis.

${ }^{9}$ An alternative specification of the model also tests whether diversified economies would be able or find it necessary to leverage on more economic sectors. To assess this, we include a measure of sectoral specialization (Herfindahl index) based on the share of regional employment in the primary, secondary and tertiary sector. A higher value of the index corresponds with a stronger specialization. The results of the model estimated with the inclusion of this control are reported in Table A3. ${ }^{10}$ Following the S3 platform classification of 3-digit sectors in each S3 strategy, the dependent variables reflect the count of targeted S3 sectors by each region at a 3-digit level. As a robustness test we have aggregated targeted sectors at 1-digit. The results of the analysis are broadly unaffected by this change.
} 


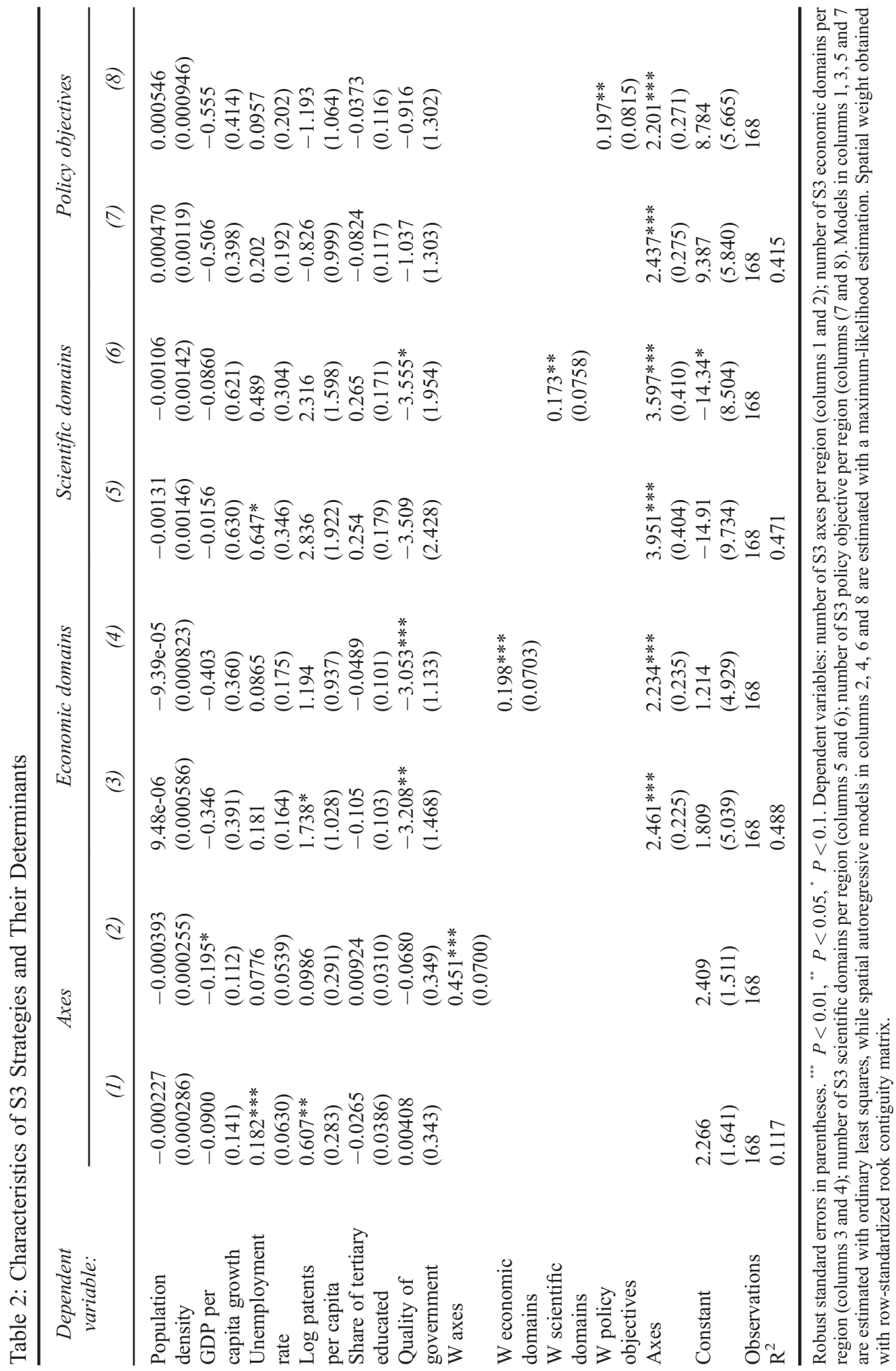


Arbix, 2001). Third, the rapid enactment of S3 at a European level may have led to copycat strategies. Finally, the economic returns of European policies are greatly influenced by whatever strategies neighbours are pursuing (Breidenbach et al., 2019). We test for this hypothesis by augmenting model (1) with the spatial lag of the dependent variable, capturing the number of axes, economic and scientific domains and policy objectives of regional neighbours. Formally, we estimate the following spatial autoregressive (SAR) model with a maximum-likelihood estimation (MLE):

$$
S 3_{r}=\alpha+\beta X_{r}+\gamma W S 3_{r}+\varepsilon_{r}
$$

where $W S 3_{r}$ is the spatial lag of the dependent variable and the row-normalized spatial weight matrix $W$ defines regional neighbours through rook contiguity. ${ }^{11}$

The sample is composed of EU NUTS regions and some small EU countries. This means that we exclude country-level observations from all countries that have both national and regional strategies (Portugal, Germany, Greece, Austria, Denmark, Poland, Romania and Sweden) and consider only their regional S3 strategies. Furthermore, the $X_{r}$ vector of explanatory variables is available only for NUTS1 and NUTS2 regions, thus no NUTS3 Scandinavian regions are considered when $X_{r}$ variables are included. These variables are also not available for non-EU countries, forcing us to exclude Ukraine, Bosnia-Herzegovina, Montenegro, Serbia, Albania, Moldova and Turkish regions.

We present the results from the econometric exploration in Table 2. For all four dependent variables, we report the results of the OLS and SAR models in consecutive columns. ${ }^{12}$ When the dependent variable is the number of economic and scientific domains or of policy objectives (columns 3-8), we also control for the number of regional axes of S3 strategies. Thus, our explanatory variables in columns 3-8 describe the relationship between a given regional socioeconomic factor and the number of domains or objectives per axis.

The results show that, on the whole, economic concentrations exert little influence on S3 strategic choices. Population density is never significantly related to S3 strategy characteristics, ${ }^{13}$ while GDP per capita growth and the unemployment rate are statistically significant only in a sub-set of the regressions (in the SAR model for the number of axes and in the OLS estimates for the number of axes and the number of scientific domains, respectively). However, the signs of the obtained coefficients are in line with expectations - with fast growth being associated with more focused strategies and higher unemployment being associated with more diffuse strategies, at least in terms of number of axes and scientific domains.

The results for the technological capacity measures are equally weak. The log of patents displays a positive coefficient in most specifications, indicating perhaps that more innovative regions tend to develop more axes and identify more investment domains, but the estimates are statistically significant in only two cases - in the numbers of axes and of

\footnotetext{
${ }^{11}$ We have experimented with alternative definitions of the $W$ matrix. Results (available upon request) are consistent across specifications.

${ }^{12}$ Given the descriptive nature of our analysis we do not concern ourselves with issues of endogeneity or inverse causality. In the SAR models the reported coefficients represent the sum of the direct and indirect effects of the explanatory variables (LeSage and Domínguez, 2012).

${ }^{13}$ As an alternative specification we have estimated our regression substituting population density with log population. The results are shown in Table A2. The coefficient of log population is only mildly significant in the first estimation (column 1 , Table A2), while it is insignificant in all other specifications. All other coefficients are unchanged from our main model.
} 
economic domains (columns 1 and 3). Instead, the human capital variable is never statistically significant and enters with different signs across specifications. It thus appears that, like the economic variables, technological capacity plays only a limited role in the design of S3 strategies. As these strategies are supposed to be devised exactly with the technological and innovation capacity of regions in mind, this finding is somewhat perplexing.

The last regional factor considered in the analysis is the quality of regional governments. In this case, the results are stronger across specifications, with the QoG not correlating significantly with the number of axes but returning a strong and consistent negative coefficient on the number of economic domains per axis. This result confirms the idea that the proliferation of investment targets in S3 strategies is a sub-optimal policy choice often conducted by regions with weaker governance structures. Regions with better institutional capacity tend to be much more selective when it comes to identifying the areas in which to invest.

In addition to the relatively poor performance of the variables representing various regional characteristics, the inclusion of spatial lags of the dependent variables leads to important findings. Across all regressions, the coefficients of the spatial lags (columns 2, 4, 6 and 8), are always positive and statistically significant. Such findings suggest that the characteristics of S3 strategies of neighbouring areas are strong predictors of how a given region develops its own strategy. While this may be due to neighbouring regions having similar needs, ${ }^{14}$ it can also signal that these regions struggle to find their S3 priorities and thus set them up by observing what their neighbours do. In other words, they may be simply replicating their approach. Hence, rather than trying to address their main bottlenecks, by prioritizing exclusively areas in which strength or potential has been identified, many EU regions mostly seem to be replicating the strategic choices of their neighbours. This would seem to cast doubt on whether S3 priorities are truly set in order to foster the selected competitive advantages of places and could raise legitimate concerns as to whether the specializations proposed and pursued by individual regions are consistent with the macro-objectives of the S3 policy framework.

We test the robustness of our findings in a number of ways. First, we replace population density with log population as control and add a variable accounting for the sectoral composition of the regions (the Herfindahl index). Second, we also run a simple SAR lag model without additional controls for regional characteristics using alternatively a spatial weights matrix $(W)$ based on inverse distance. This allows us also to include in the sample the full set of countries and regions with S3 strategies (again excluding high-level strategies when low-level ones are available). The results (see tables, , A2- A4), are very consistent, confirming the spatial lag dependence of S3 strategies and the limited role played by region-specific economic and technological characteristics.

These results also demonstrate that the tendency of regions to imitate the S3 strategies of neighbouring areas decreases with institutional quality. Table A5, reproducing the estimates with no controls and splitting the sample by different quartiles of government quality, suggests that this is the case. Regions with high quality goverment are less likely to replicate the S3 policy choices of their neighbours (insignificant spatial lag). In contrast, regions in the two lowest quartiles of government quality do so in a systematic way (positive and significant spatial lag for regions with QoG $<0$ ) (Table A5).

\footnotetext{
${ }^{14}$ Given the performance of the substantive variables in the regressions, however, such needs would not seem to be related to the economic and technological capacities of regions.
} 


\section{Conclusions}

The 2014 reform of the EU's cohesion policy brought about a significant strategic shift in development intervention across countries and regions in Europe. Despite some initial misgivings by the academics behind the concept - who described its rapid policy adoption by the EU as 'policy running ahead of theory' Foray et al., 2011, p. 1), S3 has been widely implemented even in countries outside the EU. S3 has been a substantial shift from previous policy. It marked the transition to a more place-based, bottom-up cohesion policy intended to identifying the strategic potential of each and every territory in the EU (Midtkandal and Sörvik, 2012). By using an individual entrepreneurial discovery process the aim was to adapt development intervention to the varying conditions and potential of each region and country while simultaneously raising the overall effectiveness of cohesion intervention.

This implied a thorough transformation of the old cohesion policy and extending the shift of the 'place based' approach towards a 'territorialized' industrial policy by introducing a new way of thinking about territorial development in the EU. EU countries and regions have been required in S3 strategies to identify and harness their dynamic advantages so as to unleash their growth potential. The idea was to create an efficient and smart policy capable of improving the development prospects of territories and the well-being of citizens wherever they live in Europe.

Yet, despite the importance of the reform, to date there has been virtually no evaluation of the extent to which the S3 strategies designed and implemented by countries and regions truly reflect the economic characteristics of each territory. This has been the goal of this article. We have found that S3 strategies are, by and large, very loosely connected to the characteristics of the region. With the exception of the quality of local government, the economic and scientific domains as well as the policy objectives included in the strategies do not reflect the intrinsic conditions of each region. Only territories with better governance structures and QoG have strategies that are concise and focused, meaning that these territories are pursuing clearer and less complex strategies with a more realistic and manageable number of priorities.

Rather than reflecting the intrinsic characteristics of each territory, S3 strategies to a large extent mimic what neighbouring areas are doing. A sort of copycat system - which is far more prevalent among regions with a low $\mathrm{QoG}$ - dominates, in which countries and regions define their number of economic and scientific domains and their policy priorities by what their neighbours do, rather than by their own needs and perceived potential. This accounts to a large extent for the proliferation of priorities and the lack of distinctiveness of strategies observed in our descriptive analysis.

Hence, the question that remains is whether smart specialization is really smart. Given the results of the analysis, it can be said that, in the way it has been applied, S3 is not yet smart enough. Most S3 strategies include far too many axes of intervention and the norm is that there is limited coincidence with the strengths and specialization of the territories for which the strategies were developed. Further research will be required to assess the efficiency of the massive S3 experiment once the payments linked to the 2014-20 programming period are complete. However, the tendency, especially by regions with a low government quality, mostly to imitate what the neighbours are doing and to comply only in a token way with EU requirements is likely to lead to inefficient strategies that fail 
to deliver on their promise of mobilizing local economic potential and improving development levels and quality of life across the whole of Europe.

\section{Acknowledgements}

We are grateful to Richard Whitman, the editor in charge of this article and to the three anonymous reviewers for their incisive comments and suggestions on an earlier version of it. Seminar attendants at conferences in Santiago de Compostela, Seville, Brussels and Stavanger provided useful feedback on earlier presentations. All errors or omissions are our own.

\section{Map disclaimer}

The boundaries employed in the maps do not imply the expression of any opinion on the part of the authors concerning the legal status of any country.

Correspondence:

Vassilis Monastiriotis

European Institute, London School of Economics, Houghton Street, WC2A 2AE London, UK.

email: v.monastiriotis@1se.ac.uk

\section{APPENDIX}

Table A1: Clusters of Territories/Strategies on the Basis of Economic Domains

\begin{tabular}{ccc}
\hline $\begin{array}{c}\text { Cluster; } \\
\text { no of }\end{array}$ & Specializations & Name of \\
cluster & & \\
territories/ & & \\
strategies & & \\
\hline
\end{tabular}

1, 49 Food products, fabricated metal Food and Kärnten, Oberösterreich (AT); Kentriki
products, computers and electronics, metal machinery and equipment n.e.c. manufacture Makedonia (EL); Galicia, Principado de Asturias, La Rioja (ES); Satakunta, KantaHäme, Pohjois-Pohjanmaa (FI); Champagne-Ardenne, Picardie, HauteNormandie, Bourgogne, Lorraine, Aquitaine, Midi-Pyrénées (FR); Piemonte, Valle d'Aosta, Campania, Calabria, Veneto, Friuli-Venezia Giulia, Toscana, Marche (IT); Eastern Netherlands (NL); Rogaland, Møre og Romsdal (NO); Lódzkie, Lubelskie, Wielkopolskie, Zachodniopomorskie, Opolskie (PL); Nord-Vest, Centru, Sud-Est, Sud-Muntenia, Vest (RO); Södermanlands, Östergötlands, Västmanlands, Västra Götalands (SE); Kocaeli, Konya (TR); Greater Manchester (UK); Estonia; Lithuania; Latvia; Moldova; Slovenia
2, 37 Agriculture, food processing,
Agri-food Burgenland (AT); Nordrhein-Westfalen (DE); accommodation, food services; and hospitality Anatoliki Makedonia \& Thraki, Dytiki 
Table A1: (Continued)

\begin{tabular}{lll}
\hline $\begin{array}{c}\text { Cluster; } \\
\text { no of }\end{array}$ & Specializations & Name of \\
cluster & Territories \\
strategies & & \\
\hline
\end{tabular}

computer programming, information services

3, 73 Telecoms, computer programming, information services, health scientific R\&D; human health
4, 35 Creative and entertainment activities, libraries and cultural activities, and sports and recreation activities
Makedonia, Thessalia, Ionia Nisia, Dytiki Ellada, Sterea Ellada, Attiki, Voreio Aigaio (EL); Castilla-La Mancha, Extremadura, Comunidad Valenciana, Andalucía, Canarias (ES); Päijät-Häme, Kymenlaakso, EteläKarjala, Pohjois-Savo (FI); Provence-AlpesCôte d'Azur, Martinique (FR); Puglia (IT); Sogn og Fjordane (NO); Malopolskie, Swietokrzyskie, Lubuskie (PL); Norte, Algarve, Centro, Região Autónoma dos Açores, Região Autónoma da Madeira (PT); Vojvodina (RS); Kronobergs, Kalmar, Dalarnas, Västernorrlands (SE); Montenegro Niederösterreich, Wien, Steiermark, Salzburg, Tirol, Vorarlberg (AT); Republika Srpska (BA); Flemish Region, Région Wallonne (BE); Praha (CZ); BadenWürttemberg, Bayern, Berlin, Brandenburg, Hamburg, Mecklenburg-Vorpommern, Rhineland-Pfalz, Saarland, Sachsen, Sachsen-Anhalt, Thüringen (DE); Cantabria (ES); Keski-Suomi, Etelä-Savo, PohjoisKarjala, Kainuu, Keski-Pohjanmaa, Lappi (FI); Île de France, Centre, Basse-Normandie, Nord - Pas-de-Calais, Franche-Comté, Pays de la Loire, Bretagne, Auvergne, Languedoc-Roussillon, Guadeloupe, Guyane (FR); Liguria, Abruzzo, Molise, Sicilia, Sardegna, Provincia Autonoma di Bolzano/ Bozen, Provincia Autonoma di Trento, Emilia-Romagna, Umbria, Lazio (IT); Southern Netherlands (NL); Oslo, Akershus, Hordaland (NO); Mazowieckie, Slaskie, Podkarpackie, Dolnoslaskie, Kujawsko-Pomorskie (PL); Stockholms, Uppsala, Blekinge, Skåne, Hallands, Västerbottens (SE); Kharkiv (UA); Cornwall and Isles of Scilly, Wales, Northern Ireland, England (UK); Bulgaria; Ireland; Malta; Slovakia

Creative and Syddanmark, Midtjylland, Nordjylland (DK); leisure Ipeiros, Peloponnisos, Notio Aigaio, Kriti (EL); Illes Balears (ES); Limousin, Corse, Réunion (FR); Lombardia, Basilicata (IT); Western Netherlands (NL); Hedmark, Oppland, Buskerud, Vestfold, Aust-Agder, 
Table A1: (Continued)

\begin{tabular}{ccc}
\hline $\begin{array}{c}\text { Cluster; } \\
\text { no of }\end{array}$ & Specializations & Name of \\
cluster & & \\
territories/ & & \\
strategies & & \\
\hline
\end{tabular}

Vest-Agder, Sør-Trøndelag, Nord-Trøndelag, Nordland, Troms, Finnmark (NO); Warminsko-Mazurskie (PL); Lisboa, Alentejo (PT); Örebro, Gotlands, Värmlands, Jämtlands, Norrbottens (SE); Kent, Scotland (UK)

5, 35 Electricity, gas and steam; water collection and treatment; waste collection and treatment; and other waste management services
Energy and Brussels-Capital Region (BE); Bremen, resources Hessen, Niedersachsen, Schleswig-Holstein (DE); Hovedstaden, Sjælland (DK); País Vasco, Comunidad Foral de Navarra, Aragón, Comunidad de Madrid, Castilla y León, Cataluña, Región de Murcia (ES); Etelä-Pohjanmaa, Pohjanmaa, Pirkanmaa, Helsinki-Uusimaa, Varsinais-Suomi (FI); Alsace, Poitou-Charentes, Rhône-Alpes (FR); Northern Netherlands (NL); Østfold (NO); Podlaskie, Pomorskie (PL); Nord-Est, Sud-Vest Oltenia (RO); Gävleborgs (SE); Cherkasy (UA); Northamptonshire (UK); Cyprus; Croatia; Hungary; Luxembourg

Table A2: Log Population as Control

\begin{tabular}{|c|c|c|c|c|c|c|c|c|}
\hline \multirow{2}{*}{$\begin{array}{l}\text { Dependent } \\
\text { variable: }\end{array}$} & \multicolumn{2}{|c|}{ Axes } & \multicolumn{2}{|c|}{ Economic domains } & \multicolumn{2}{|c|}{ Scientific domains } & \multicolumn{2}{|c|}{ Policy objectives } \\
\hline & (1) & (2) & (3) & (4) & (5) & (6) & (7) & (8) \\
\hline Log population & $\begin{array}{l}0.473^{*} \\
(0.283)\end{array}$ & $\begin{array}{l}0.562^{* *} \\
(0.254)\end{array}$ & $\begin{array}{l}-0.770 \\
(0.813)\end{array}$ & $\begin{array}{l}-0.400 \\
(0.847)\end{array}$ & $\begin{array}{l}-0.236 \\
(1.405)\end{array}$ & $\begin{array}{l}0.139 \\
(1.454)\end{array}$ & $\begin{array}{l}-0.800 \\
(1.035)\end{array}$ & $\begin{array}{l}-0.500 \\
(0.970)\end{array}$ \\
\hline GDP pc growth & $\begin{array}{l}-0.0701 \\
(0.138)\end{array}$ & $\begin{array}{l}-0.164 \\
(0.110)\end{array}$ & $\begin{array}{l}-0.355 \\
(0.396)\end{array}$ & $\begin{array}{l}-0.400 \\
(0.356)\end{array}$ & $\begin{array}{l}0.0637 \\
(0.635)\end{array}$ & $\begin{array}{l}-0.0211 \\
(0.616)\end{array}$ & $\begin{array}{l}-0.544 \\
(0.386)\end{array}$ & $\begin{array}{l}-0.592 \\
(0.410)\end{array}$ \\
\hline $\begin{array}{l}\text { Unemployment } \\
\text { rate }\end{array}$ & $\begin{array}{l}0.183^{* * *} \\
(0.0650)\end{array}$ & $\begin{array}{l}0.0817 \\
(0.0533)\end{array}$ & $\begin{array}{l}0.178 \\
(0.166)\end{array}$ & $\begin{array}{l}0.0892 \\
(0.174)\end{array}$ & $\begin{array}{l}0.661^{*} \\
(0.348)\end{array}$ & $\begin{array}{l}0.497 \\
(0.304)\end{array}$ & $\begin{array}{l}0.194 \\
(0.189)\end{array}$ & $\begin{array}{l}0.0919 \\
(0.202)\end{array}$ \\
\hline Log patents pc & $\begin{array}{l}0.479 \\
(0.325)\end{array}$ & $\begin{array}{l}-0.0590 \\
(0.296)\end{array}$ & $\begin{array}{l}1.912^{*} \\
(1.004)\end{array}$ & $\begin{array}{l}1.293 \\
(0.961)\end{array}$ & $\begin{array}{l}2.805 \\
(1.887)\end{array}$ & $\begin{array}{l}2.202 \\
(1.635)\end{array}$ & $\begin{array}{l}-0.616 \\
(1.002)\end{array}$ & $\begin{array}{l}-1.032 \\
(1.089)\end{array}$ \\
\hline $\begin{array}{l}\text { Share of tertiary } \\
\text { educated }\end{array}$ & $\begin{array}{l}-0.0526 \\
(0.0366)\end{array}$ & $\begin{array}{l}-0.0275 \\
(0.0296)\end{array}$ & $\begin{array}{l}-0.0774 \\
(0.0976)\end{array}$ & $\begin{array}{l}-0.0408 \\
(0.0974)\end{array}$ & $\begin{array}{l}0.203 \\
(0.175)\end{array}$ & $\begin{array}{l}0.213 \\
(0.167)\end{array}$ & $\begin{array}{l}-0.0336 \\
(0.115)\end{array}$ & $\begin{array}{l}0.00282 \\
(0.112)\end{array}$ \\
\hline $\begin{array}{l}\text { Quality of } \\
\text { Government } \\
\text { W axes }\end{array}$ & $\begin{array}{l}0.302 \\
(0.371)\end{array}$ & $\begin{array}{l}0.324 \\
(0.359) \\
0.450^{* * * *} \\
(0.0694)\end{array}$ & $\begin{array}{l}-3.582^{* * *} \\
(1.431)\end{array}$ & $\begin{array}{l}-3.222^{* * * *} \\
(1.182)\end{array}$ & $\begin{array}{l}-3.218 \\
(2.454)\end{array}$ & $\begin{array}{l}-3.164 \\
(2.030)\end{array}$ & $\begin{array}{l}-1.568 \\
(1.426)\end{array}$ & $\begin{array}{l}-1.330 \\
(1.355)\end{array}$ \\
\hline $\begin{array}{l}\text { W economic } \\
\text { domains }\end{array}$ & & & & $\begin{array}{l}0.192^{* * *} \\
(0.0712)\end{array}$ & & & & \\
\hline
\end{tabular}


Table A2: (Continued)

\begin{tabular}{|c|c|c|c|c|c|c|c|c|}
\hline \multirow{2}{*}{$\begin{array}{l}\text { Dependent } \\
\text { variable: }\end{array}$} & \multicolumn{2}{|c|}{ Axes } & \multicolumn{2}{|c|}{ Economic domains } & \multicolumn{2}{|c|}{ Scientific domains } & \multicolumn{2}{|c|}{ Policy objectives } \\
\hline & (1) & (2) & (3) & (4) & (5) & (6) & (7) & (8) \\
\hline $\begin{array}{l}\text { W scientific } \\
\text { domains }\end{array}$ & & & & & & $\begin{array}{l}0.178^{* *} \\
(0.0761)\end{array}$ & & \\
\hline $\begin{array}{l}\text { W policy } \\
\text { objectives }\end{array}$ & & & & & & & & $\begin{array}{l}0.190^{* *} \\
(0.0823)\end{array}$ \\
\hline Axes & & & $\begin{array}{l}2.486^{* * *} \\
(0.218)\end{array}$ & $\begin{array}{l}2.255^{* * * *} \\
(0.237)\end{array}$ & $\begin{array}{l}3.980^{* * * *} \\
(0.403)\end{array}$ & $\begin{array}{l}3.599^{* * *} \\
(0.416)\end{array}$ & $\begin{array}{l}2.456^{* * *} \\
(0.279)\end{array}$ & $\begin{array}{l}2.218^{* * * *} \\
(0.275)\end{array}$ \\
\hline Constant & $\begin{array}{l}-3.715 \\
(3.231)\end{array}$ & $\begin{array}{l}-4.628 \\
(3.606)\end{array}$ & $\begin{array}{l}11.69 \\
(12.76)\end{array}$ & $\begin{array}{l}6.407 \\
(11.95)\end{array}$ & $\begin{array}{l}-11.18 \\
(21.79)\end{array}$ & $\begin{array}{l}-15.55 \\
(20.47)\end{array}$ & $\begin{array}{l}19.40 \\
(14.95)\end{array}$ & $\begin{array}{l}14.93 \\
(13.70)\end{array}$ \\
\hline Observations & 168 & 168 & 168 & 168 & 168 & 168 & 168 & 168 \\
\hline R-squared & 0.138 & & 0.495 & & 0.475 & & 0.415 & \\
\hline
\end{tabular}

Robust standard errors in parentheses. ${ }^{* * *} P<0.01,{ }^{* *} P<0.05,{ }^{*} P<0.1$. Dependent variables: number of S3 axes per region (columns 1, 2); number of S3 economic domains per region (columns 3, 4); number of S3 scientific domains per region (columns 5, 6); number of S3 policy objective per region (columns 7, 8). Models in columns 1, 3, 5, 7 are estimated with OLS, while SAR models in columns 2, 4, 6, 8 are estimated with a maximum-likelihood estimation. Spatial weight obtained with row-standardized rook contiguity matrix.

Table A3: Control for Sectoral Specialization

\begin{tabular}{|c|c|c|c|c|c|c|c|c|}
\hline \multirow{2}{*}{$\begin{array}{l}\text { Dependent } \\
\text { variable: }\end{array}$} & \multicolumn{2}{|c|}{ Axes } & \multicolumn{2}{|c|}{ Economic domains } & \multicolumn{2}{|c|}{ Scientific domains } & \multicolumn{2}{|c|}{ Policy objectives } \\
\hline & (1) & (2) & (3) & (4) & (5) & (6) & (7) & (8) \\
\hline Population density & $\begin{array}{l}-5.22 \mathrm{e}-05 \\
(0.000324)\end{array}$ & $\begin{array}{l}-0.000317 \\
(0.000268)\end{array}$ & $\begin{array}{l}0.000407 \\
(0.000598)\end{array}$ & $\begin{array}{l}0.000131 \\
(0.000866)\end{array}$ & $\begin{array}{l}-0.000817 \\
(0.00143)\end{array}$ & $\begin{array}{l}-0.000793 \\
(0.00148)\end{array}$ & $\begin{array}{l}0.000392 \\
(0.00125)\end{array}$ & $\begin{array}{l}0.000337 \\
(0.000986)\end{array}$ \\
\hline GDP pc growth & $\begin{array}{l}-0.200 \\
(0.146)\end{array}$ & $\begin{array}{l}-0.237^{*} \\
(0.121)\end{array}$ & $\begin{array}{l}-0.608 \\
(0.414)\end{array}$ & $\begin{array}{l}-0.541 \\
(0.396)\end{array}$ & $\begin{array}{l}-0.343 \\
(0.685)\end{array}$ & $\begin{array}{l}-0.268 \\
(0.683)\end{array}$ & $\begin{array}{l}-0.454 \\
(0.453)\end{array}$ & $\begin{array}{l}-0.416 \\
(0.454)\end{array}$ \\
\hline $\begin{array}{l}\text { Unemployment } \\
\text { rate }\end{array}$ & $\begin{array}{l}0.182^{* * *} \\
(0.0611)\end{array}$ & $\begin{array}{l}0.0806 \\
(0.0540)\end{array}$ & $\begin{array}{l}0.190 \\
(0.162)\end{array}$ & $\begin{array}{l}0.1000 \\
(0.175)\end{array}$ & $\begin{array}{l}0.659^{*} \\
(0.348)\end{array}$ & $\begin{array}{l}0.506^{*} \\
(0.305)\end{array}$ & $\begin{array}{l}0.200 \\
(0.194)\end{array}$ & $\begin{array}{l}0.0843 \\
(0.202)\end{array}$ \\
\hline Log patents pc & $\begin{array}{l}0.612^{* *} \\
(0.281)\end{array}$ & $\begin{array}{l}0.115 \\
(0.291)\end{array}$ & $\begin{array}{l}1.782^{*} \\
(1.027)\end{array}$ & $\begin{array}{l}1.264 \\
(0.940)\end{array}$ & $\begin{array}{l}2.890 \\
(1.936)\end{array}$ & $\begin{array}{l}2.381 \\
(1.600)\end{array}$ & $\begin{array}{l}-0.834 \\
(1.003)\end{array}$ & $\begin{array}{l}-1.237 \\
(1.063)\end{array}$ \\
\hline $\begin{array}{l}\text { Share of tertiary } \\
\text { educated }\end{array}$ & $\begin{array}{l}0.00799 \\
(0.0407)\end{array}$ & $\begin{array}{l}0.0221 \\
(0.0343)\end{array}$ & $\begin{array}{l}-0.0255 \\
(0.116)\end{array}$ & $\begin{array}{l}-0.0108 \\
(0.111)\end{array}$ & $\begin{array}{l}0.352 \\
(0.219)\end{array}$ & $\begin{array}{l}0.320^{*} \\
(0.192)\end{array}$ & $\begin{array}{l}-0.0980 \\
(0.133)\end{array}$ & $\begin{array}{l}-0.0773 \\
(0.127)\end{array}$ \\
\hline $\begin{array}{l}\text { Quality of } \\
\text { Government }\end{array}$ & $\begin{array}{l}0.00109 \\
(0.333)\end{array}$ & $\begin{array}{l}-0.0671 \\
(0.349)\end{array}$ & $\begin{array}{l}-3.214^{* *} \\
(1.482)\end{array}$ & $\begin{array}{l}-3.070^{* * *} \\
(1.132)\end{array}$ & $\begin{array}{l}-3.518 \\
(2.437)\end{array}$ & $\begin{array}{l}-3.557^{*} \\
(1.953)\end{array}$ & $\begin{array}{l}-1.035 \\
(1.307)\end{array}$ & $\begin{array}{l}-0.905 \\
(1.299)\end{array}$ \\
\hline $\begin{array}{l}\text { Sectoral } \\
\text { composition } \\
\text { (Herfindhal Index) }\end{array}$ & $\begin{array}{l}-5.558^{* *} \\
(2.266)\end{array}$ & $\begin{array}{l}-2.240 \\
(2.544)\end{array}$ & $\begin{array}{l}-12.99 \\
(8.383)\end{array}$ & $\begin{array}{l}-7.055 \\
(8.495)\end{array}$ & $\begin{array}{l}-16.20 \\
(15.67)\end{array}$ & $\begin{array}{l}-9.252 \\
(14.46)\end{array}$ & $\begin{array}{l}2.564 \\
(10.07)\end{array}$ & $\begin{array}{l}6.996 \\
(9.515)\end{array}$ \\
\hline $\mathrm{W}$ axes & & $\begin{array}{l}0.438^{* * *} \\
(0.0719)\end{array}$ & & & & & & \\
\hline $\begin{array}{l}\text { W economic } \\
\text { domains }\end{array}$ & & & & $\begin{array}{l}0.181^{* *} \\
(0.0734)\end{array}$ & & & & \\
\hline $\begin{array}{l}\text { W scientific } \\
\text { domains }\end{array}$ & & & & & & $\begin{array}{l}0.162^{* *} \\
(0.0780)\end{array}$ & & \\
\hline
\end{tabular}


Table A3: (Continued)

\begin{tabular}{|c|c|c|c|c|c|c|c|c|}
\hline \multirow{2}{*}{$\begin{array}{l}\text { Dependent } \\
\text { variable: }\end{array}$} & \multicolumn{2}{|c|}{ Axes } & \multicolumn{2}{|c|}{ Economic domains } & \multicolumn{2}{|c|}{ Scientific domains } & \multicolumn{2}{|c|}{ Policy objectives } \\
\hline & (1) & (2) & (3) & (4) & (5) & (6) & (7) & (8) \\
\hline $\begin{array}{l}\text { W policy } \\
\text { objectives }\end{array}$ & & & & & & & & $\begin{array}{l}0.209^{* *} \\
(0.0826)\end{array}$ \\
\hline Axes & & & $\begin{array}{l}2.407^{* * *} \\
(0.226)\end{array}$ & $\begin{array}{l}2.224^{* * *} \\
(0.235)\end{array}$ & $\begin{array}{l}3.884^{* * *} \\
(0.401)\end{array}$ & $\begin{array}{l}3.582^{* * *} \\
(0.411)\end{array}$ & $\begin{array}{l}2.448^{* * *} \\
(0.275)\end{array}$ & $\begin{array}{l}2.217^{* * *} \\
(0.271)\end{array}$ \\
\hline Constant & $\begin{array}{l}5.228^{* * *} \\
(1.968)\end{array}$ & $\begin{array}{l}3.599^{*} \\
(2.026)\end{array}$ & $\begin{array}{l}8.853 \\
(6.483)\end{array}$ & $\begin{array}{l}5.091 \\
(6.785)\end{array}$ & $\begin{array}{l}-6.132 \\
(11.93)\end{array}$ & $\begin{array}{l}-9.358 \\
(11.52)\end{array}$ & $\begin{array}{l}7.996 \\
(7.523)\end{array}$ & $\begin{array}{l}4.956 \\
(7.685)\end{array}$ \\
\hline Observations & 168 & 168 & 168 & 168 & 168 & 168 & 168 & 168 \\
\hline R-squared & 0.138 & & 0.495 & & 0.475 & & 0.415 & \\
\hline
\end{tabular}

Robust standard errors in parentheses. ${ }^{* * *} P<0.01,{ }^{* *} P<0.05, \quad P<0.1$. Dependent variables: number of S3 axes per region (columns 1,2); number of S3 economic domains per region (columns 3, 4); number of S3 scientific domains per region (columns 5, 6); number of S3 policy objective per region (columns 7, 8). Models in columns 1, 3, 5 and 7 are estimated with OLS, while spatial autoregressive models in columns 2, 4, 6 and 8 are estimated with a maximum-likelihood estimation. Spatial weight obtained with row-standardized rook contiguity matrix.

Table A4: Robustness Test - Spatial Autoregressive Model, All Regions and Countries in Sample

\begin{tabular}{|c|c|c|c|c|c|c|c|c|}
\hline \multirow{2}{*}{$\begin{array}{c}\begin{array}{c}\text { Dependent } \\
\text { variable: }\end{array} \\
W:\end{array}$} & \multicolumn{2}{|c|}{ Axes } & \multicolumn{2}{|c|}{ Economic domains } & \multicolumn{2}{|c|}{ Scientific domains } & \multicolumn{2}{|c|}{ Policy objectives } \\
\hline & Contiguity & Inv. dist. & Contiguity & Inv. dist. & Contiguity & Inv. dist. & Contiguity & Inv. dist. \\
\hline W axes & $\begin{array}{l}(1) \\
0.346^{* * *} \\
(0.0575)\end{array}$ & $\begin{array}{l}(2) \\
0.413^{* * *} \\
(0.124)\end{array}$ & (3) & (4) & (5) & (6) & (7) & (8) \\
\hline $\begin{array}{l}\text { W economic } \\
\text { domains }\end{array}$ & & & $\begin{array}{l}0.352^{* * *} \\
(0.0609)\end{array}$ & $\begin{array}{l}0.484^{* * *} \\
(0.164)\end{array}$ & & & & \\
\hline $\begin{array}{l}\text { W scientific } \\
\text { domains }\end{array}$ & & & & & $\begin{array}{l}0.472^{* * *} \\
(0.0579)\end{array}$ & $\begin{array}{l}0.616^{* * *} \\
(0.184)\end{array}$ & & \\
\hline $\begin{array}{l}\text { W policy } \\
\text { objectives }\end{array}$ & & & & & & & $\begin{array}{l}0.451^{* * *} \\
(0.0610)\end{array}$ & $\begin{array}{l}0.284 \\
(0.214)\end{array}$ \\
\hline Constant & $\begin{array}{l}3.363^{* * *} \\
(0.313)\end{array}$ & $\begin{array}{l}3.596^{* * *} \\
(0.443)\end{array}$ & $\begin{array}{l}11.27^{* * *} \\
(1.159)\end{array}$ & $\begin{array}{l}11.39^{* * *} \\
(1.966)\end{array}$ & $\begin{array}{l}13.50^{* * *} \\
(1.658)\end{array}$ & $\begin{array}{l}14.33^{* * *} \\
(3.138)\end{array}$ & $\begin{array}{l}9.184^{* * * *} \\
(1.095)\end{array}$ & $\begin{array}{l}12.76^{* * * *} \\
(2.277)\end{array}$ \\
\hline Observations & 243 & 243 & 243 & 243 & 243 & 243 & 243 & 243 \\
\hline
\end{tabular}

Standard errors in parenthesis. ${ }^{* * *} P<0.01, " “ P<0.05, " ~ P<0.1$. Dependent variables: number of S3 axes per region (columns 1 and 2); number of S3 economic domains per region (columns 3 and 4); number of S3 scientific domains per region (columns 5 and 6); number of S3 policy objective per region (columns 7 and 8). Models are estimated with a maximum-likelihood estimation. Spatial weight obtained with row-standardized rook contiguity matrix in columns $(1,3$, 5 and 7) and with inverse distance in columns 2, 4, 6 and 8). The sample consists of the territories included in Table 2, plus all Scandinavian regions and non-EU territories with S3 strategies. In countries where only some regions have submitted a regional strategy, all regions that did not submit a strategy have been assigned the value of zero to axes and domains. For example, in the Czech Republic, where only Prague has submitted a regional strategy, all regions except Prague have been assigned the value of zero to axes and domain. 


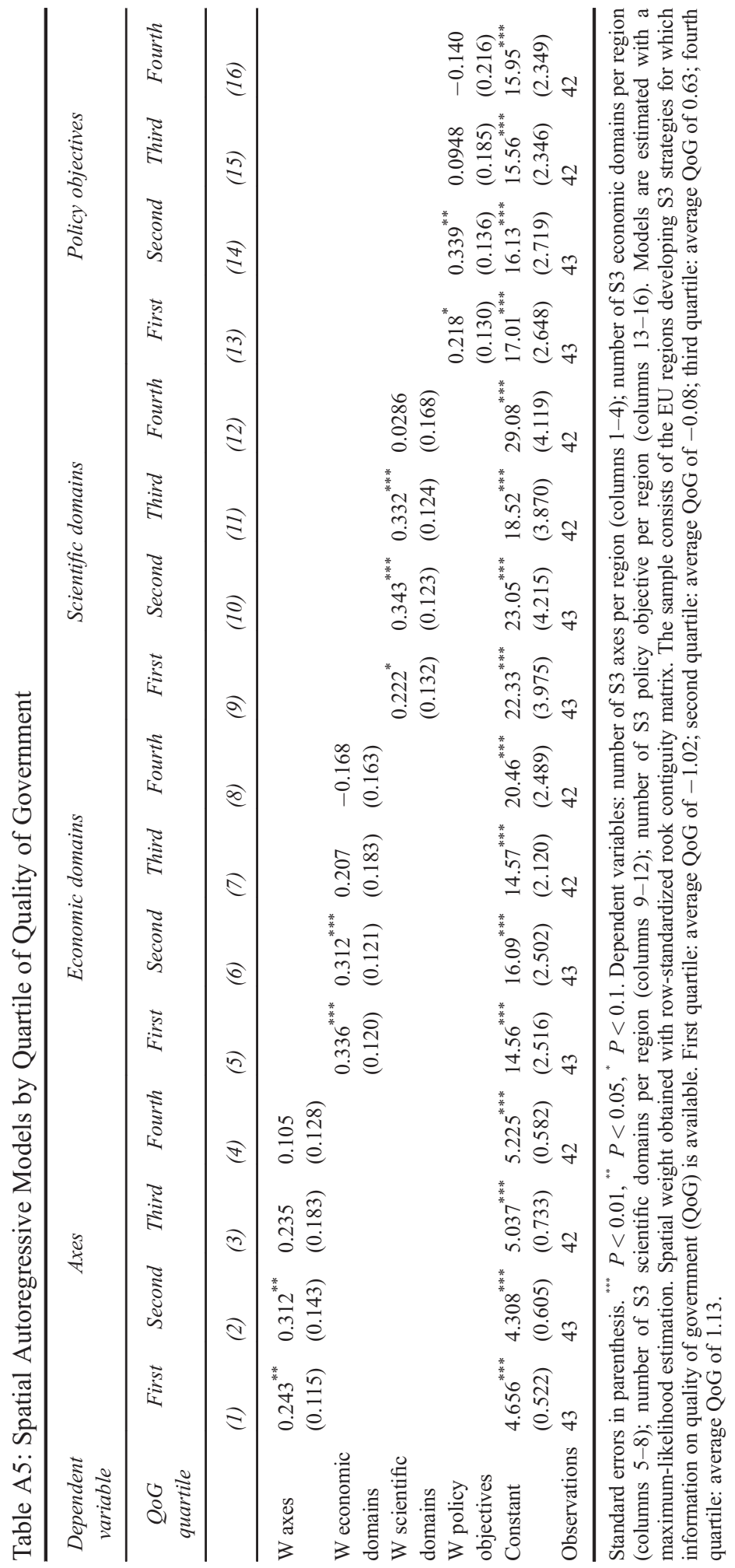




\section{References}

Asheim, B.T., Boschma, R. and Cooke, P. (2011) 'Constructing Regional Advantage: Platform Policies Based on Related Variety and Differentiated Knowledge Bases'. Regional Studies, Vol. 45, No. 7, pp. 893-904.

Asheim, B., Grillitsch, M. and Trippl, M. (2017) 'Smart Specialisation as an Innovation-driven Strategy for Economic Diversification'. In Radosevic, S. et al. (eds.), Advances in the Theory and Practice of Smart Specialisation, Elsevier Science Publishers, Amsterdam, pp. 74-97.

Balland, P.A., Boschma, R., Crespo, J. and Rigby, D.L. (2019) 'Smart Specialization Policy in the European Union: Relatedness, Knowledge Complexity and Regional Diversification'. Regional Studies, Vol. 53, No. 9, pp. 1252-68.

Barca, F. (2009) An Agenda for a Reformed Cohesion Policy: A Place-based Approach to Meeting European Union Challenges and Expectations (Brussels: European Commission).

Barca, F., McCann, P. and Rodríguez-Pose, A. (2012) 'The Case for Regional Development Intervention: Place-based versus Place-neutral Approaches'. Journal of Regional Science, Vol. 52, No. 1, pp. 134-52.

Boschma, R. (2014) 'Constructing Regional Advantage and Smart Specialization: Comparison of two European Policy Concepts'. Scienze Regionali, Vol. 13, No. 1, pp. 51-68.

Boschma, R. and Iammarino, S. (2009) 'Related Variety, Trade Linkages, and Regional Growth in Italy'. Economic Geography, Vol. 85, No. 3, pp. 289-311.

Bottazzi, L. and Peri, G. (2003) 'Innovation and Spillovers in Regions: Evidence from European Patent Data'. European Economic Review, Vol. 47, No. 4, pp. 687-710.

Breidenbach, P., Mitze, T. and Schmidt, C.M. (2019) 'EU Regional Policy and the Neighbour's Curse: Analyzing the Income Convergence Effects of ESIF Funding in the Presence of Spatial Spillovers'. JCMS, Vol. 57, No. 2, pp. 388-405.

Camagni, R., Capello, R. and Lenzi, C. (2014) 'A Territorial Taxonomy of Innovative Regions and the European Regional Policy Reform: Smart Innovation Policies’. Scienze Regionali, Vol. 13, No. 1, pp. 69-106.

Capello, R. and Kroll, H. (2016) 'From Theory to Practice in Smart Specialization Strategy: Emerging Limits and Possible Future Trajectories'. European Planning Studies, Vol. 24, No. 9, pp. 1393-406.

Charles, D., Gross, F. and Bachtler, J. (2012) 'Smart Specialisation and Cohesion Policy - A Strategy for All Regions'. IQ-Net Thematic Paper, Vol. 30, No. 2, pp. 1-51.

Charron, N., Dijkstra, L. and Lapuente, V. (2014) 'Regional Governance Matters: Quality of Government within European Union Member States'. Regional Studies, Vol. 48, No. 1, pp. 68-90.

Combes, P.P., Duranton, G. and Gobillon, L. (2008) 'Spatial Wage Disparities: Sorting Matters!' Journal of Urban Economics, Vol. 63, No. 2, pp. 723-42.

Crescenzi, R. (2005) 'Innovation and Regional Growth in the Enlarged Europe: The Role of Local Innovative Capabilities, Peripherality, and Education'. Growth and Change, Vol. 36, No. 4, pp. 471-507.

Crescenzi, R., De Filippis, F. and Pierangeli, F. (2015) 'In Tandem for Cohesion? Synergies and Conflicts between Regional and Agricultural Policies of the European Union'. Regional Studies, Vol. 49, No. 4, pp. 681-704.

Crescenzi, R., Fratesi, U. and Monastiriotis, V. (2017) 'The EU Cohesion Policy and the Factors Conditioning Success and Failure: Evidence from 15 Regions'. Regions Magazine, Vol. 305, No. 1, pp. 4-7.

Crescenzi, R., de Blasio, G. and Giua, M. (2020) 'Cohesion Policy Incentives for Collaborative Industrial Research: Evaluation of a Smart Specialisation Forerunner Programme'. Regional Studies, Vol. 54, No. 10, pp. 1341-1353. 
David, P., Foray, D. and Hall, B. (2009) 'Measuring Smart Specialisation: The Concept and the Need for Indicators'. Knowledge for Growth Expert Group, pp. 1-37. Available online: https://www.scribd.com/document/80115599/MeasuringSmart-Specialisation-The-conceptand-the-need-for-indicators (accessed on 16 December 2020).

Di Cataldo, M. and Monastiriotis, V. (2020) 'Regional Needs, Regional Targeting and Regional Growth: An Assessment of EU Cohesion Policy in UK Regions'. Regional Studies, Vol. 54, No. 1, pp. 35-47.

Farhauer, O. and Kröll, A. (2012) 'Diversified Specialisation - Going One Step beyond Regional Economics' Specialisation-Diversification Concept'. Review of Regional Research, Vol. 32, No. 1, pp. 63-84.

Farole, T., Rodríguez-Pose, A. and Storper, M. (2011) 'Cohesion Policy in the European Union: Growth, Geography, Institutions'. JCMS, Vol. 49, No. 5, pp. 1089-111.

Fedeli, V., Lenzi, C., Briata, P. and Pedrazzini, L. (2019) EU Regional and Urban Policy: Innovations and Experiences from the 2014-2020 Programming Period (London: Springer).

Foray, D. (2015) Smart Specialisation: Opportunities and Challenges for Regional Innovation Policy (Abingdon: Routledge).

Foray, D., David, P.A. and Hall, B.H. (2009) 'Smart Specialisation. The Concept'. Knowledge Economists Policy Brief No. 9, June.

Foray, D., David, P.A. and Hall, B.H. (2011) 'Smart Specialisation'. In From Academic Idea to Political Instrument, the Surprising Career of a Concept and the Difficulties Involved in Its Implementation'. MTEI Working Paper, November.

Frenken, K., Van Oort, F.G. and Verburg, T. (2007) 'Related Variety, Unrelated Variety and Regional Economic Growth'. Regional Studies, Vol. 41, No. 5, pp. 685-97.

Gianelle, C., Guzzo, F. and Mieszkowski, K. (2020) 'Smart Specialisation: What Gets Lost in Translation from Concept to Practice?' Regional Studies, Vol. 54, No. 10, 1377-1388.

Gordon, I. (2010). Territorial Competition. In Pike, A., Rodríguez-Pose, A. and Tomaney, J. (eds). Handbook of Local and Regional Development (London: Routledge), pp. 52-64.

Henke, R., Benos, T., De Filippis, F., Giua, M., Pierangeli, F. and Pupo D'Andrea, M.R. (2018) 'The New Common Agricultural Policy: How Do Member States Respond to Flexibility?' JCMS, Vol. 56, No. 2, pp. 403-19.

Hughes, A. (2012) 'Choosing Races and Placing Bets: UK National Innovation Policy and the Globalisation of Innovation Systems'. In Greenaway, D. (ed.) The UK in a Global World: How Can the UK Focus on Steps in Global Value Chains that Really Add Value? (London: Business Innovation and Skills), pp. 37-70.

Iacobucci, D. (2014) 'Designing and Implementing a Smart Specialisation Strategy at Regional Level: Some Open Questions'. Scienze Regionali, Vol. 13, No. 1, pp. 107-26.

Iacobucci, D. and Guzzini, E. (2016) 'Relatedness and Connectivity in Technological Domains: Missing Links in S3 Design and Implementation'. European Planning Studies, Vol. 24, No. 8, pp. 1511-26.

Incaltarau, C., Pascariu, G.C., and Surubaru, N.-C. (2020) Evaluating the Determinants of EU Funds Absorption across Old and New Member States - the Role of Administrative Capacity and Political Governance. JCMS: Journal of Common Market Studies, Vol. 58, No. 4, pp. 94161. https://doi.org/10.1111/jcms.12995.

LeSage, J.P. and Domínguez, M. (2012) 'The Importance of Modeling Spatial Spillovers in Public Choice Analysis'. Public Choice, Vol. 150, No. 3, pp. 525-45.

Mazzucato, M. (2018) 'Mission-oriented Innovation Policies: Challenges and Opportunities'. Industrial and Corporate Change, Vol. 27, No. 5, pp. 803-15.

McCann, P. and Ortega-Argilés, R. (2014) 'The Role of the Smart Specialisation Agenda in a Reformed EU Cohesion Policy’. Scienze Regionali, Vol. 13, No. 1, pp. 15-32. 
McCann, P. and Ortega-Argilés, R. (2015) 'Smart Specialization, Regional Growth and Applications to European Union Cohesion Policy’. Regional Studies, Vol. 49, No. 8, pp. 1291-302.

McCann, P. and Ortega-Argilés, R. (2016) 'The Early Experience of Smart Specialization Implementation in EU Cohesion Policy'. European Planning Studies, Vol. 24, No. 8, pp. 1407-27.

Mechtel, M. and Potrafke, N. (2013) 'Electoral Cycles in Active Labor Market Policies'. Public Choice, Vol. 156, No. 1-2, pp. 181-94.

Midtkandal, I. and Sörvik, J. (2012) 'What is Smart Specialisation'. Nordregio News, Vol. 5, pp. 3-6.

Morgan, K. (2015) 'Smart Specialisation: Opportunities and Challenges for Regional Innovation Policy'. Regional Studies, Vol. 49, No. 3, pp. 480-2.

Revelli, F. (2002) 'Testing the Taxmimicking versus Expenditure Spill-over Hypotheses Using English Data'. Applied Economics, Vol. 34, No. 14, pp. 1723-31.

Rodríguez-Pose, A. (2020) 'Institutions and the Fortunes of Territories'. Regional Science Policy \& Practice, Vol. 12, No. 3, pp. 371-86.

Rodríguez-Pose, A. and Arbix, G. (2001) 'Strategies of Waste: Bidding Wars in the Brazilian Automobile Sector'. International Journal of Urban and Regional Research, Vol. 25, No. 1, pp. 134-54.

Rodríguez-Pose, A. and Di Cataldo, M. (2015) 'Quality of Government and Innovative Performance in the Regions of Europe'. Journal of Economic Geography, Vol. 15, No. 4, pp. 673 706.

Rodríguez-Pose, A. and Fratesi, U. (2004) 'Between Development and Social Policies: The Impact of European Structural Funds in Objective 1 Regions'. Regional Studies, Vol. 38, No. 1, pp. 97-113.

Rodríguez-Pose, A., Di Cataldo, M. and Rainoldi, A. (2014) 'The Role of Government Institutions for Smart Specialisation and Regional Development'. JRC Working Papers JRC88935.

Rodrik, D. (2004) 'Industrial Policy for the Twenty-First Century'. Mimeo, Harvard University. Available online at: at https://j.mp/2nRcNXi. Last accessed 10 December 2020.

Sotiriou, A. and Tsiapa, M. (2015) 'The Asymmetric Influence of Structural Funds on Regional Growth in Greece'. Environment and Planning C: Government and Policy, Vol. 33, No. 4, pp. $863-81$. 